\title{
From Fleck's Denkstil to Kuhn's Paradigm: Conceptual Schemes and Incommensurability
}

Babette Babich

Fordham University, babich@fordham.edu

Follow this and additional works at: https://fordham.bepress.com/phil_babich

Part of the Continental Philosophy Commons, History of Philosophy Commons, Medicine and $\underline{\text { Health Commons, Philosophy of Science Commons, and the Sociology of Culture Commons }}$

\section{Recommended Citation}

Babich, Babette, "From Fleck’s Denkstil to Kuhn's Paradigm: Conceptual Schemes and Incommensurability" (2003). Articles and Chapters in Academic Book Collections. 7.

https://fordham.bepress.com/phil_babich/7 
This article was downloaded by:[Ingenta Content Distribution]

On: 23 December 2007

Access Details: [subscription number 768420433]

Publisher: Routledge

Informa Ltd Registered in England and Wales Registered Number: 1072954

Registered office: Mortimer House, 37-41 Mortimer Street, London W1T 3JH, UK

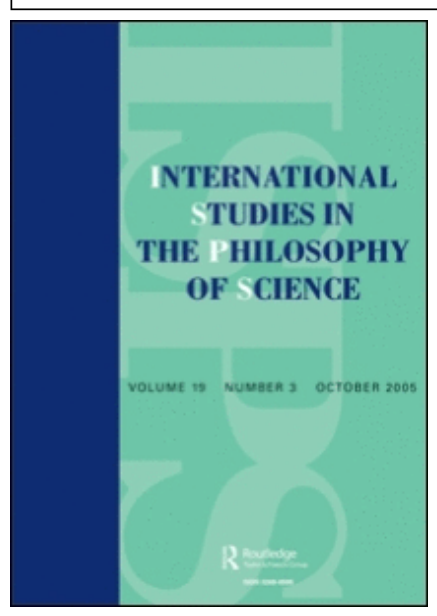

\section{International Studies in the Philosophy of Science}

Publication details, including instructions for authors and subscription information: http://www.informaworld.com/smpp/title content=t713427740

From Fleck's Denkstil to Kuhn's paradigm: conceptual schemes and incommensurability

Babette E. Babich ${ }^{\text {a }}$

a Department of Philosophy, Fordham University, New York, NY, USA and

Georgetown University, Washington, DC, USA.

Online Publication Date: 01 March 2003

To cite this Article: Babich, Babette E. (2003) 'From Fleck's Denkstil to Kuhn's paradigm: conceptual schemes and incommensurability', International Studies in the Philosophy of Science, 17:1, 75 - 92

To link to this article: DOI: $10.1080 / 02698590305236$

URL: http://dx.doi.org/10.1080/02698590305236

\section{PLEASE SCROLL DOWN FOR ARTICLE}

\section{Full terms and conditions of use: http://www.informaworld.com/terms-and-conditions-of-access.pdf}

This article maybe used for research, teaching and private study purposes. Any substantial or systematic reproduction, re-distribution, re-selling, loan or sub-licensing, systematic supply or distribution in any form to anyone is expressly forbidden.

The publisher does not give any warranty express or implied or make any representation that the contents will be complete or accurate or up to date. The accuracy of any instructions, formulae and drug doses should be independently verified with primary sources. The publisher shall not be liable for any loss, actions, claims, proceedings, demand or costs or damages whatsoever or howsoever caused arising directly or indirectly in connection with or arising out of the use of this material. 


\title{
From Fleck's Denkstil to Kuhn's paradigm: conceptual schemes and incommensurability
}

\author{
BABETTE E. BABICH \\ Department of Philosophy, Fordham University, New York, NY, USA and Georgetown \\ University, Washington, DC, USA
}

\begin{abstract}
This article argues that the limited influence of Ludwik Fleck's ideas on philosophy of science is due not only to their indirect dissemination by way of Thomas Kuhn, but also to an incommensurability between the standard conceptual framework of history and philosophy of science and Fleck's own more integratedly historico-social and praxis-oriented approach to understanding the evolution of scientific discovery. What Kuhn named "paradigm" offers a periphrastic rendering or oblique translation of Fleck's Denkstil/Denkkollektiv, a derivation that may also account for the lability of the term "paradigm". This was due not to Kuhn's unwillingness to credit Fleck but rather to the cold war political circumstances surrounding the writing of The Structure of Scientific Revolutions. Following a discussion of Fleck's anatomical allusions, I include a brief discussion of Aristotle (on menstruation and darkened mirrors) and conclude with a reference to the productivity of error in Mach and Nietzsche.
\end{abstract}

\section{Incommensurability and stylized resistance}

If it is tragic, it is also routine in the disciplinary project of philosophy of science that Ludwik Fleck's important contributions to understanding the research traditions and practices of science came to attention only via the indirect route of their influence on Thomas Kuhn, himself a figure of conflicted influence in history and philosophy of science.

In what follows, I argue that the limited scope of the influence of Fleck's ideas was not merely that his work was (at the time) available only in German but was rather due to a plain incommensurability between the standard conceptual framework for philosophical or even sociological studies of science and Fleck's historico-social and praxisoriented approach to scientific progress. ${ }^{1}$ The incommensurability ${ }^{2}$ was terminological and thus conceptual; it reflected and constituted an insurmountable tension between the kind of language and thinking evident in Fleck's The Genesis and Development of a Scientific Fact and the conceptual language appropriate to what one might still call the "received view" in philosophy of science. The cognitive dissonance resultant from such incommensurability meant that the scope of Fleck's influence was limited to encounters ruled more by chance than congeniality. Indeed, Fleck's viewpoints continue to be opposed to the entrenched tradition in philosophy of science, a tradition more interested in exploring the specifically normative and practical research programme of problem 
solving instigated by Karl Popper, pursued by, e.g. Larry Laudan and central to establishment philosophy of science today.

In the case of Ludwik Fleck, the conceptual problem of incommensurability turns around the question of style: style both in terms of Fleck's express invocation of the "style of a thought" interior to science, an idea strongly resisted in traditional philosophy of science, and in terms of the tacit style of Fleck's own writing, geared as it was to the interests of biological science, with illustrations from medical research practices, rather than physics or chemistry. Fleck's conceptual terminology centres around "thought style" [Denkstil] and the related if even more elusive conception of a "thought collective" [Denk-Kollektiv] and the latter's emergent properties.

Fleck's notion of style had its origins in the sociological theories of Karl Mannheim, ${ }^{3}$ who in turn drew on earlier developments. The concept of Stil (and the related notion of Struktur) had enjoyed an extensive currency and influence as an aesthetic conception in the study of art and culture at end of the 19th century and continuing into the 20th century, an influence associated with the work and epoch of Heinrich Wölfflin. ${ }^{4}$ This same concept of style is still expressed today, as when one speaks of a "painter's style" or more specifically a "period style" (Hellenism, Classicism, Impressionism, Italian Futurism, but also the "style" of a Rembrandt, or a Vermeer, or a Van Gogh, etc.). The well-known exchange between Mannheim and Erwin Panofksy ${ }^{5}$ documents the crossover of this idea from what the Germans call Kunstwissenschaft (not altogether the equivalent of art history) to the sciences. ${ }^{6}$

Yet more alien than the notion of style for history and philosophy of science was Fleck's notion of thought communities (which Fleck conceived as functioning throughout history as well as contemporaneously in modern scientific research practice) because such an expressly collective image of scientific research challenges Western liberal ideas of individualism and freedom-nor is it an accident that these ideas are more and not less crucial to contemporary images of science in the West. In opposition to the contemporary Western cultural emphasis on the individual and its correlative emphasis on individual scientific genius, Fleck's philosophic reflection on the collective working or dynamic function of science foregrounds the ineluctable dependence of the individual upon or within any given, historical, thought collective. As Fleck reflected in his landmark 1947 essay, "To Look, To See, To Know", the concept of a scientific thought collective offends the intellectual sensibilities of those affected, and for good reason: "scientists, most frequently individualists, do not want to see the collective nature of thinking. What would remain of their renowned genius?" (Fleck, 1986 [1947], p. 151). But, for Fleck, the individual cannot escape or indeed surpass the collective (this is why he adverts to the notion of genius in this context): the thought collective of any era is the taken-for-granted, precisely unreflected culture of that same era. Not a consciously received or dominant perspective of thought, the collective is what phenomenologists and hermeneuticists call the "world"-assumed in advance of a particular research tradition. For this horizonal reason, a given scientific thought collective is the perspective within which what is scientifically conceived can be conceived as such. ${ }^{7}$ As Fleck's later editors, Robert S. Cohen and Thomas Schnelle (1986, p. xxi), explain, "the individual member of a collective is not free to be scientifically active otherwise than on the basis of his stylized socialization. His thought must start with the propositions created by the collective". In Fleck's own words,

the ordinary scientist of the day finds that 'scientific truth' is a complex mental construction, inseparably connected with investigative techniques, statistical 
interpretations and manifold conventions. He knows that it may often be expressed only in a special jargon and be intelligible only after a prolonged professional training. In his opinion, 'scientific truth' depends on 'conjunctures', i.e., on the scientific opportunity, on the environment and on the personal influence of the author. (Fleck, 1986 [1960], p. 153)

Maintaining that scientific truth is ineluctably social, Fleck takes the disciplinary relevance of sociology of knowledge to be no less central to an understanding of science than history itself.

Yet to advert to sociology of science (in particular) or else (more broadly) to history of science is only to compound the troubles of incommensurability. Sociology of science or, more radically, sociology of knowledge, particularly natural science, is far from an entrenched, much less a secure, discipline vis-à-vis science (witness the recent fury of the "science wars", fading only because the more radical proponents of sociological, anthropological, rhetorical or cultural studies of science have been chastened and are in due retreat: rendering unto science what is science's, on the precise terms dictated by fealty to the hierarchical ideal of science as such) or philosophy of science. Nor was this conflict between worldviews (think of Dilthey or Mannheim) less inchoate in Fleck's era. ${ }^{8}$ In the words of more than one commentator, Fleck was "ahead of his time". 9

It is important to note that sociology of science per se (or sociology of knowledge), apart from distant disciplinary icons like Robert Merton, but qua sociological studies, that is again: qua quintessentially social science, has yet to enjoy an uncontested status vis-à-vis "science" proper, that is: natural science. Nor is this particularly remarkable because, historically, the social sciences in their current "scientific" form are younger than the natural sciences and were quite conscientiously formed in that same, mathematized image. ${ }^{10}$ And in the waning of the "science wars", sociology has been compelled to defend itself precisely as a science, ${ }^{11}$ given studies offering an exact sociology of "laboratory life" or the "manufacture of knowledge". The history of science itself remains a methodological and conceptual problem for philosophy of science and the rational ideal of science because (unlike other "social" studies of science) history of science refers very precisely to the way science "in fact" (as one might say) was generated and how science actually or factually developed in real scientific practice. Thus more than anything else, it may be argued, it is new approaches to the history of science (deriving from conceptual changes in the doing of history itself) that have begun to undermine the standard or received view of analytic philosophy of science. Many scholars credit Steven Shapin and Simon Schaffer's Leviathan and the Air Pump, but if this book was one of the first to enjoy widespread attention, it did so only in the wake of a shift that had already begun, certainly beginning with Herbert Butterfield and A. C. Crombie but also as far back as Pierre Duhem. For one example, relevant here because it blurs the borders drawn between science and pseudoscience in philosophy of science, an increasingly sober account of the historical relation between alchemy and natural science may be seen to be taking form, following the first-wave efforts of scholars such as Frances Yates and Betty Jo Teeter Dobbs but also Allan Debus and Peter Dear. In particular, Lawrence Principe's work on Robert Boyle in his The Aspiring Adept offers an importantly nuanced countermeasure to Shapin and Schaffer. Internally, philosophy of science itself has begun to attend to its own history, as may be witnessed in the collection Origins of Logical Positivism, edited by Ronald Giere and Alan Richardson, and continuing vigorously in Michael Friedman's still-too-positivist but overt attempt to bridge the analytic-continental divide, especially in his Parting of the Ways. ${ }^{12}$ With regard 
to sociology and even hermeneutics, the contributions of John Ziman, Rom Harré, and Stephen Toulmin in the mainstream, but also Jan Golinski and Bruno Latour, among others, on the socio-anthropological side of the debate, testify to a renewed sensibility to the lived and cultural practice of science. ${ }^{13}$

In the context of social theories of scientific culture, it is important if not without controversy, to advert to the camp quality or fairy-tale oddness of the Sokal hoax. For the hoax, far from being the kind of joke Sokal pretends it was, has yet to be examined as an all-too-calculated ruse, as the ruse of a ruse-with all the tendentiousness that such an expression would suggest.

Throughout the past century, both critics and proponents of science alike have been invited to accept or receive only what certified scientists endorse as an authorized definition of science. This is the joke at work in the original locus or butt of the joke as it was played upon the editors of Social Text, just as it was a joke played on and among friends. But it is essential to emphasize here that Sokal's hoax may well have been a kind of double hoax, effected by means of an all-too-perfect "in" on the game. It is a relevant bit of evidence (or gossip) ${ }^{14}$ that Sokal was a friend of Social Text editor and meteorological enthusiast, Andrew Ross, that Sokal met his current wife at a party at Ross's home-relevant because exactly not nothing follows from such social or friendly circumstantial evidence. Academics who know editors should know better than to think that any kind of vetting or review-blind or expert, humanist or scientist, or what have you-would be the only thing at work in such friendly cases. Almost too trivially good to be true, it seems the hoax was "cooked"-a thoroughly academic set-up.

An overawed confidence in the ultimacy of current physical science is at work in Sokal's own presumption (like that of his more renowned colleague Steven Weinberg) ${ }^{15}$ regarding the finished adequacy of science as critically perfect and quite literally beyond critique. This totalizing confidence in science has sometimes been saddled by critics with a suffix - calling it scientism ${ }^{16}$ - to hold it at a critical distance from more nuanced views on science. But in the context of philosophy or sociology of science, etc., a charge of scientism is about as much a reproof as the charge of deism in a religious community. The same joke continues to work in the wake of commentary on the story and (surprise, surprise) no one who writes on it can be found to say anything but "how wonderful" 17 it was just to think how Sokal rode into town to show up the postmoderns, the Derrideans, the feminists, the anthropologists and sociologists of science, the social constructivists - at which point, in a spontaneous reflex of reflexivity, certain scholars are then to be seen busily shoring up their own legacy by severing their own work from any even putatively or remotely science-critical perspective. I name here only Bruno Latour and Ian Hacking, where other names, are, despite themselves, lesser names. ${ }^{18}$ The philosopher of science, one can only be led to believe, must eschew critique if he or she is to be taken as "knowing anything" about science. Thus, in the past, one has ruled out the philosophical perspective of a Nietzsche or a Heidegger or even the later Husserl. One cannot be, and one must affirm that one has never been, a member of any such critical party.

\section{Thought styles and the paradigm of anatomy: bones of contention}

We have noted the relevance of terminological incommensurabilities in Fleck's thinking to indicate the conceptual difficulties presented for the tradition of philosophy of science.

Just how egregious these difficulties were-and, in large measure, remain —is best 
seen by noting a striking conceptual limitation of the important collection, Cognition and Fact: Materials on Ludwik Fleck, including English translations of Fleck's own essays dating from 1934 to 1960 as well as profiling leading scholarly responses to Fleck both in his own time and in recent times (Cohen \& Schnelle, 1986). For not a single essay in this still pathbreaking collection shows any comprehension of the function of the biological dimension of science or medical metaphor for Fleck, as the very key to Fleck's philosophical thought on science and scientific knowledge. Why this should be so has a good deal to do with the mathematization (the logicized image) of science and the intractability (at least until fairly recently) of the biomedical sciences to this ideal or iconic image of science. More important than the reasons for this neglect of biomedical science are the implications for coming to terms with or understanding Fleck's thought.

Without a foundational background in biology, the task of registering the full scope of Fleck's arguments seems to have been impossible, even in a sympathetic collection dedicated to advancing his reception. ${ }^{19}$ Indeed, in Cognition and Fact, the exception that might be thought to be found in the contributions by biologists or medical scientists repeats a generally critical perspective on Fleck, highlighting his medical limitations and, quite in the face of current practice, attributing more sensitivity to the workings of the immune system and much more holism to medical research practice than happens in fact to be the case, an optimistic illusion given both the global AIDS crisis-which same crisis not incidentally confirms Fleck's critical charge contra the conceptual deficiencies characteristic of modern medicine itself and its search for singular causal agency (i.e. HIV) - and the medical profession's oddly uncritical support of the healing promise of genetic re-engineering, chances inspired by the mere idea of decoding the human genome. The reigning thought style (and collective rule) of today's biological as well as today's medical science increasingly approximates physical science, and even, in the case of genetics, information science. By contrast, Fleck's biology was the classic microbiology of the early 20th century. As Fleck (1960) contended for his own reasons, the current biomedical paradigm does not necessarily constitute an unqualified advance (see, on Fleck, Tsouyopoulos, 1982 and Zajiček, 1992; on modern biomedical progress, see Lewontin, 1991).

Fleck challenges the standard story of the triumphalist emergence of modern medical science as a break with the benightedly unobserving medieval point of view as an eruption into modernity-whereby the main empirical advance in modern science proceeded by literally taking a look (through the microscope, in the case of Hooke, or, more canonically in Galileo's case, the telescope). This standard, objectivist perspective was for Fleck absurd. Although it is often claimed that the medieval perspective on observation of the natural world was blinded by prejudice and superstition (as the so-called "Age of Belief"), Fleck countered that one could not, "assert that a medieval scientist did not have any positive relationship to observation" (Fleck, 1986 [1935], p. 73). Key for Fleck was the conceptual schema within which whatever was observed or noted would be able to be so observed:

Looking and seeing at that time differed from the present day, but it would be a sign of naiveté to think that a man of those days was asleep, and roused himself from his sleep only during the Renaissance.... [A scientist in] the 16th century could find bones in the neighbourhood of cemeteries and study them, but the Middle Ages simply lacked any intellectual need of such observations; when looking at a bone, one could see only what one could find in books ... (Fleck, 1986 [1935], p. 74) 
For Fleck, those very books tell the story as much of scientific discoveries as of the ruling interests and the shifts in interests that accompany discoveries:

In 17th-century anatomy books we find long chapters describing and enumerating the so-called ossa sesamoidea which are disposed of with a few sentences in today's textbooks: currently they are, so to speak, outside the osseous system and of little interest from the ontogenetic, morphological, or physiological viewpoint. But at that time they were important because of certain ancient myths according to which from one of such bones there will develop 'sicut planta ex semine' the complete body to appear at the Last Judgment. (Fleck, 1986 [1935], p. 76, trans. modified)

To take a further example relating to the influence of religious convictions on scientific perceptions, the 14 th- or 15th-century anatomist or physician simply "knew" that the male of the human species lacked a rib. They did not need to, more decisively, they could not check for themselves to "see" that this was not so (nor, as beyond Fleck, historians are best placed to explain, could simply pointing out such a "fact" before then-contemporary eyes have been able to alter such convictions). ${ }^{20}$

Fleck's point is that contemporary anatomical preoccupations are as comparatively "incorrigible" as such putatively erroneous medieval views because, from our own perspective, our own contemporary views are as invisible as and as unquestionable to us as their own intrinsically medieval preoccupations were to the anatomists of past times. We see such medieval preoccupations as preoccupations only because they are not our own. Contrasting the modern with the medieval scholar, Fleck concludes that "what is of importance to us, is for him inessential, inexplicable, alien, just as, on the contrary, his own thinking is alien to us" (Fleck, 1986 [1935], p. 74).

Fleck was not a pioneer of social studies of knowledge or scientific culture per se. Such disciplinary approaches to science studies, including anthropology as well as sociology, tend in theoretical expression and practice to be epistemically uncritical, for they themselves are articulated within specific disciplinary or "scientific frames". And Fleck's concern, which is what renders his thinking proper to philosophy of science, was addressed to what he called epistemology, which is why he ended up by elevating the promise (not the reality) of sociology to the height of a veritable mathematics or methodological structure for the sake of science. ${ }^{21}$ This epistemological concern reflects the logical limits of scientific discovery (research) and scientific justification (theory and philosophy). By reflecting on the historical question of thought styles and the relevance of precisely collective communities of thought and the emergent properties that characterize such styles of thought interior to such communities in specific cultural and historical context, Fleck sought to show that that same history and range of cultures adumbrated nothing less ambitious than the material dialectic of science in real and ineluctably communal research practice. $^{22}$

\section{Kuhn: the genesis of a paradigm}

Famously, and this is why we are able in the insular context of English-language philosophy of science to talk about Fleck at all, it was no one less important than Thomas Kuhn who read Fleck's The Genesis and Development of a Scientific Fact (Fleck, 1935), as part of his own scholarship and as part of the preparation for his own work on The Structure of Scientific Revolutions (Kuhn, 1970 [1962]). Because, as Kuhn reports in retrospect, he read German only "badly", he was compelled, as he also emphasizes, 
to read and re-read Fleck. ${ }^{23}$ But more significant than such a painstaking reading is that Kuhn happened upon Fleck's book in an intensifying constellation of ideological circumstances rife in an era that regarded from the new, more than postmodern, vantage of the 21 st century seems as distant as Fleck's vanished world.

Kuhn's time spanned pre-war and wartime history and his crucial and formative intellectual work found expression during the era of the post-war world known as the cold war. In America proper, the climate of the cold war reflected the still virulent McCarthyism dominating everything from art to criminal justice and including the academy - or Ivory Tower as it was then unquaintly regarded. If the McCarthy era in the land of the free and the brave was not Stalinism, it nevertheless had exactly repressive parallels. Much of the social and intellectual repression characterizing the 1950s and 1960s expressed this climate of fear. The change that began to take place in the late 1960s (really into the 1970 s and, alas, coming there to an unsung and unmarked dead-end) saw a world change in fashion and lifestyles, if not in politics. But if today, we no longer hear about the socialist or communist threat - to use the language of the cold war-that is not because we have become more nuanced about the psychoanalytic projection implicit in the language of a "communist threat" or about the multifarious and complex dimensionality of political forms like socialism or communism, but rather because like so many of the varied biological species that have become extinct in the long course of the last century, the threat of socialism/communism has been vanquished. The end of the cold war corresponds to the extirpation of the political regimes of socialism and communism itself, almost like the phantasm of democracy in the USA. ${ }^{24}$ But this does not quite mean that we've evolved beyond the inanity of McCarthyism.

Kuhn, it is well known, if also more virulently asserted in German-language studies of Fleck's influence on Kuhn than it is in English contexts, did not fully credit Fleck. ${ }^{25}$ But I do not think it an exaggeration to suppose that, in the political climate of the 1950s and despite the manifest relevance of Fleck's study, Kuhn, even had he wished to, could not have invoked Fleck's name, most especially not his words: this is where my claim of incommensurability stands. And if, more radically, one claims, as I do, that Kuhn's "paradigm" is a periphrastic construction derived from and effectively translating Fleck's Denkstil/Denkkollektiv, this was not because Kuhn did not understand Fleck's terminology but because only such a paraphrase was, per impossibile, possible.

In Kuhn's case, the author himself exemplifies the worst aspect of the so-called authorial fallacy. Like works of art, words like paradigm (or thought style or hermeneutics) may be seen to have lives and fortunes of their own, apart from and often alien to their originators. ${ }^{26}$ Expressing, just as Kuhn maintains, the salient core of Fleck's The Genesis and Development of a Scientific Fact, the notion of a "thought style" presented Kuhn with a research palimpsest, interpretive armature, or background structure for The Structure of Scientific Revolutions, providing an exactly deployable heuristic device for articulating the historical course of scientific change or revolution in science. And Kuhn needed such a structure just because it was otherwise unavailable, as Kuhn himself rightly emphasizes in his 1976 introduction to Fleck's Genesis and Development of a Scientific Fact. ${ }^{27}$

The problem of citing Fleck's precedent for Kuhn had less to do with Fleck's "Polish-inflected" German (this is a misleading assertion on Kuhn's part-as Fuller repeats the claim on Kuhn's behalf, surveying the historical circumstances of Kuhn's life and work (Fuller, 2000, p. 60n.) ${ }^{28}$-for there is no "false friend", as language teachers say, to trip one up in the translation of Denkstil [thought style] or Denkkollektiv [thought collective]). Not a problem of translation, the problem corresponds to the political restrictions of Kuhn's era (from the 1940s through the 1950s and early 1960s) entailing 
that Kuhn could not adequately refer to Fleck's terminology. Kuhn in his 1962 book could not have used such dangerously loaded terms as "thought collectives"—or "thought styles"-for the perfectly banal reasons we still attribute to and name "politics". For this reason, paradigm became Kuhn's term of choice. The language of collectives or thought styles would have evoked precisely reactive reactions in a time of the paranoia and anxieties expressed in words like brainwashing, propaganda, the Iron Curtain and the Iron State, and the inscrutable evil of Eastern Europe, of Russia and (this is all that is left today) China. And in 1976, the later Kuhn, writing an introduction to the belated translation of Fleck's book (Kuhn, 1979), remained careful to underscore his personal, exactly gut distance from these very same terms. Even after so much time, one may hear the echo of Western anxiety vis-à-vis the image of the "collective" as the anti-individualist, veritably mindless, socialist "horde".

Nothing but the then-times themselves gave birth to the unhappy coinage of the term paradigm - among whatever other reasons there may also have been for the term. This same historical echo reverberates through Kuhn's own revealingly overfrank, at times uncomprehending, sometimes brittle autobiographical reflections. And in The Road Since Structure (Kuhn, 2000), in Kuhn's interview with Aristides Baltas, Kostas Gavroglu, and Vassili Kindi, even the most hermeneutically impoverished reader must note the relevance of Kuhn's most repeated word "anger" (Baltas et al., 2000, pp. 255323) - articulating his actions in terms of a fundamental, choleric impatience. This reflexive reaction to his own academic legacy does not contradict as much as it complements the contextual circumstances (or very Fleckian "genesis") of Kuhn's book, as Fuller outlines it in his own study of Kuhn and the development of Kuhn's own influence in the broader culture of the academy itself. ${ }^{29}$

In this context it is worth recalling the anecdote that Kuhn found significant enough to dedicate a great proportion of his own brief introduction to Fleck to retelling it. Kuhn reports that his own mentor, Harvard President James Bryant Conant, who became US High Commissioner for Germany, referred to the German title of Fleck's book, Die Entstehung und Entwicklung einer wissenschaftliche Tatsache, in conversation with a German associate, after Kuhn had related his discovery of Fleck to him. For Conant, the borrowed reference backfired, as such borrowed references often do in transcultural contexts. Conant's German associate responded to the mention of the title of Fleck's work with a spontaneous denunciation of the concept as such: recoiling from its titular proposition in a bravely, determinedly naive positivism that is the unchanged ideal of philosophy of science, latterly called realism, then betrayed by the stolid conviction that the-facts-are-the-facts. By definition, as Conant's Teutonic interlocutor painstakingly instructed him, and hence contra the concept of Entstehung and Entwicklung-the one thing Tatsachen or "facts" did not as such have was anything like a "genesis" and the last thing they are able to do is "develop". Facts are just "discovered" as what they plainly are. Sidestepping such debacles, Kuhn eschewed Fleck's terminology and spoke instead of paradigms and paradigm shifts, normal and revolutionary science. ${ }^{30}$

But this genesis explains why Kuhn himself was never able adequately to specify the meaning of or to defend or even to understand or to accept a conceptual constellation he had only first discovered in Fleck. ${ }^{31}$ It also explains the parallel resistance to these same ideas in philosophy of science as such. As Lothar Schäfer (1977, p. 25) reflects: "keeping Kuhn's thorough-going dependency on Fleck in mind, one must draw the obvious conclusion that the key presupposition for [the concept per se of] revolution in the philosophy of science has to be found in the ahistorical consciousness" of philosophy of science. ${ }^{32}$ Only a lack of historical background sophistication (what the Germans call 
Wissenschaft with respect to history itself) internal to the discipline of history and philosophy of science could have permitted the enduring influence of the idea of revolution as a "fact" so very contrary to the complex dynamic of the empirical history of science. ${ }^{33}$

\section{The importance of error: Ernst Mach, Ludwik Fleck, and Nietzsche on the relativity of truth}

In the wake of Kuhn's The Structure of Scientific Revolutions-that is, internal to the hermeneutic history of its reception and effects-Steven Shapin can begin his small volume on The Scientific Revolution with the grand declaration that there was no scientific revolution (Shapin, 1996, p. 1). Shapin says this non-revolutionary thing for the same historical reasons that Fleck himself could have given where history of science outlines neither unbroken scientific advances nor patent revolutions. Thus Fleck emphasized the precisely non-cumulative (non-linear) character of scientific progress in contrast to the cumulative character of past error.

For Fleck, as, more abstrusely, for Ernst Mach, error was not to be condemned to the dustbin of history because from the same historical perspective it is impossible to know exactly where true error lies or in what it consists or inheres. Nor can we be sure, indeed, that the greater error would not be found in our own inevitably presentist account of what we now regard as past errors. For Fleck, as for Mach and for Nietzsche, it is as difficult to say what error is as it is to say what truth is-however much this important and radically post-Kantian corollary may be expected to dismay latter-day Popperians. ${ }^{34}$ Our perception of error is precisely as context-dependent as our perception of scientific truth.

For both Fleck and Mach, as scientists designing research possibilities and perspectives, the so-called "errors" of the past represented the critically important resources of future scientific truth. Past errors were regarded as scientific reserves, realms exactly not to be forgotten. ${ }^{35}$ By contrast with the ideal of timelessly routine presentism, ${ }^{36}$ which is the ideal of scientific progress, Fleck's historical reading of the history of scientific truth and the facts of the same offers a sustained reading of nothing less than the erring truth of, for example, astrology as such. For Fleck, astrological preoccupations and assumptions articulated nothing less indispensable than that very errant context without which the scientific concept of what we today regard as the disease entity, ${ }^{37}$ i.e. syphilis, as such, could not have come to stand: where a concrete historical genesis and conceptual, contextual development was requisite for the scientific discovery of what we name the modern disease entity as such. These questions also address, as we shall see below, the definition of health, for, as Georges Canguilhem has argued, the ideal of health reflects not a natural kind or default condition of bodily balance or stasis but a construction or even a comfortable fantasy. ${ }^{38}$

To take a further illustration of this historical context, it is relevant that the contextual question is one that is never mentioned in present-day debates concerning Aristotle's account of the mirror-reddening gaze of the menstruating woman. ${ }^{39}$ The author of one overview rightly decries the sexism of present-day readings, readings which for their own part challenge Aristotle's patented prejudices (Saunders, 2002, pp. 304-305). ${ }^{40}$ But what, in Fleck's name, I am here invoking as "context" would transmute the cultural advantage of gender sensitivity and Whiggish prejudice. The contextual primacy of error in the case of the mirror-reddening gaze turns upon the critical issue that ought perhaps to be made of the historically differential matter of fact that ancient mirrors are not made of glass but polished metal: bronze, copper, silver, etc. 
And all such metals and their alloys (even without attending to the sobering limits of today's understanding of ancient metallurgy) - have the special characteristic that from the moment they are fashioned (and it is for this reason very relevant, albeit not to commentators on this question, that Aristotle duly specifies a brand-new mirror), such metal mirrors oxidize. Newly fashioned (like newly polished) metal mirrors tarnish upon exposure to the ambient atmosphere, an atmosphere including not only factors of climate but also relevantly in the case of personal mirrors, the humidity of respiration and perspiration, and notably the acidity in human breath-that same acidity that undergoes circadian alterations in the course of the day as well as in response to longer-term hormonal changes, the same acidity that is so little a merely theoretical construct that its effects have closed the caves at Lascaux to visitors in recent years, and so on. That is, even the most recent commentator on this debate does not, just as a good scientist would not, raise the question of the possible locus of truth in what we are (already) persuaded to have been error or, indeed, ancient Greek, male prejudice.

But Fleck argues differently. It is the central thesis of Fleck's study that conceptions of disease now regarded as mistaken were not merely regrettable detours on the way to the ultimate discovery of the modern scientific conceptual understanding of syphilis but essential or "happy" errors necessary for this discovery. These erroneous constructs, changing throughout different historical eras, work in a non-linear but branched development of the changing scientific accounts we have of syphilis, perhaps (but not necessarily or only) because syphilis is the kind of pleonastic disease that it is (i.e. syphilis manifests itself differently at different stages and its manifestations differ in different individuals), and therefore requiring a varied array of approaches to it (profiles). Rather than a disease of the skin (the locus of symptomatic infection), what is essential is the blood and beyond that the nervous system itself. Fleck explored this constellation of disease profiles (diseases of the skin, the blood, the immune and nervous system) by detailing a history of therapeutic measures-where for Fleck the easiest thing of all is to cure a disease, understanding it in all cases and in all its possible profiles is quite another thing. In the context of this historical inquiry, Fleck interposed a quasi-synchronic account of the progressive character of the disease. Even after Fleck, even after the decisive challenges to the agent theory of disease, we continue to identify (mistakenly on Fleck's account) syphilis with the spirochaete and to search for a singular or decisive aetiology of all diseases in our search for cures for the same. This one-size-fitsall scheme of illness and health persists and may well stand behind the current enthusiasms for the genome project (one gene-one disease) as the latest instauration of this causal conviction.

As a scourge from heaven, under the sign of venereal influence, syphilitic disease could be transmitted through the blood, as the sins of the fathers are visited on the sons. For this insight, the religious, astrological, mythological lore of the disease was not merely a mistaken track in the history of scientific progress towards modernity and the disease entity that we think to limit to and so to identify with the spirochaete itself (qua disease vector/agent) but the veritably erring path of the scientific discovery of and the emergence of scientific fact itself. Exactly this transition was required, Fleck argues-as, in a similar vein, Principe has retraced the similar importance of alchemy exactly for the sake of (and not as blocking) the development of chemistry (Principe, 1998)-in order to identify or "discover" a connection between a disease of the skin (the integument as the symptomatic locus where primary, specifically observable symptoms of syphilis are manifest) and the blood. It was the developmentally pleonastic character of the disease of syphilis that made its scientific study and resolution particularly difficult-and not 
only, as a politically stylish argument that still recurs in the context of HIV research, the taboo of sexual anxiety and prejudice. ${ }^{41}$ More critically in terms of the development of the modern disease concept, what, asks the serologist, has a disease of the skin, the province of dermatology, to do with the blood? And what, we may and we ought still to ask, has a disease characterized by serological changes to do with the nervous system, the spinal fluid, the organism as a whole? How/why does syphilis, if untreated, progress in approximately 25 per cent of those affected, to the later stages of this disease? Why 25 per cent? Or for a contemporary and all-too-esoteric perspective, is there a relationship between syphilis and HIV? Such questions address the problem of infection-and immunology and public health-in nuce. ${ }^{42}$ For Fleck, who was one of the first to correlate not only the elevated count of leukocytes but also (so Fleck argued, though this, significantly has not yielded a research tradition in leukergy, the branch of medical science discovered by Fleck but which he failed to institutionalize) ${ }^{43}$ other characteristic changes of those same leukocytes as specific indices of immune response (notably, so Fleck argued, as adequate to differentiate between bacterial and viral infection and more), these questions remain to be posed in a precisely complex (to emphasize the scientific and research point Fleck insisted upon) context.

It was error, i.e. the very erroneous idea of a scourge, metaphorically expressed in terms of the "unscientific" (to use Fleck's specification) concept of "befouled" or "bad blood" that was a requisite, indispensable element in the development of the scientific concept of the strangely unstable disease entity that Fleck himself in perfectly scientific sobriety did not finally identify with the spirochaete. ${ }^{44}$ Bacteriological agency alone was insufficient to explain the aetiology of the disease as such, specifically in its pleonastic character, and which, in the wake of AIDS and the ongoing global crisis of the same, we have begun to understand as requiring greater specification, focusing more upon the host organism and immune system than the concept of the disease entity as such. ${ }^{45}$

Fleck thus maintained (for the sake of preserving the same complexity he thought indispensable to medical research) that error was to be conserved (Nietzsche went further in this, as in everything, and spoke of "cultivating error as the mother womb of knowledge" ${ }^{, 6}$ ): preserving past error like an attic full of things out of style, or a basement collection of discarded and forgotten artefacts, broken, or bent, which are nonetheless kept out of the prudential recognition that they might turn out to be useful-once dominant sclerotic perspectives (no matter if we call them Fleckian thought styles or Kuhnian paradigms) have been altered by as yet unanticipated influences.

Critically - logically - it is only if our truths are true, only if we can be certain of our scientific point of departure, that the process of science can be a more or less ideally algorithmic and heuristically banal (Kuhn's "ordinary") affair (this is the contention Laudan's progressive programme eliminates by designating as "revolutionary" the everyday ideal of science, whereby revolution turns out to be a matter of normal, scientific problem solving).

Ludwik Fleck's conviction, which he shared with Ernst Mach, was that the complex riches surrounding an abandoned path might hold a useful key for us when retracing our steps after sufficient anomalies, or encounters with the limits of the ruling paradigm (as the current scientific thought style) moves us to do so.

\section{Acknowledgements}

I am grateful to James W. McAllister for his constructive suggestions as well as to three anonymous referees for their comments. 


\section{Notes}

1. It is instructive that the greatest part of the literature devoted to Fleck explores not the significance of his philosophical account of scientific progress but rather the history of neglect. Indeed the translation of Fleck (1979 [1935]) came about only as a deliberate corrective, and it is conceivable that, had no one noticed the parallels between Fleck's and Kuhn's views on the communal dynamic of scientific practice in Kuhn (1970 [1962]), Fleck might never have seen the light of day in English translation.

2. By incommensurability here and in what follows, I refer to the simple badness of fit between Fleck's terminology and conceptual schemata in related areas of the philosophy of science. This is also the sense in which Alasdair MacIntyre (1981) speaks of incommensurability and the general sense in which Hacking (1982, 1983, pp. 12-14) characterizes it precisely with reference to Kuhn. I thus do not refer to the more specialized use of the term and the correspondingly vast literature addressed to it in analytic philosophy and philosophy of science (however, for a start, see Hacking's own reference list, Hacking, 1983, p. 278). I thank an anonymous reviewer for calling attention to the need to make this distinction an explicit one.

3. See Schäfer and Schnelle's introduction to the Suhrkamp edition of Fleck (1986). Thaddeus Trenn (1979) specifically alludes to the distinction to be made between Fleck's use of paradigm and thought style, emphasizing its debt to Mannheim. In his biography of Kuhn, Steve Fuller (2000, p. 60n.) makes much of the fact that Fleck does not expressly allude to Mannheim. But the habit of documenting all one's references and allusions is not the only way of making such references and, in general, references that are common knowledge are not commonly tied to a specific name, especially where such a limitation would have been inaccurate. Due to its art-historical provenance in the spheres associated with Heinrich Wölfflin and Alois Riegl, Stil had a far broader and expressly interdisciplinary currency beyond Mannheim's 1925 usage: see the following note below. See, too, Hacking (1992), although in this essay Hacking draws on Crombie (1952) for his reading of "style".

4. See Heinrich Wölfflin (1915) and Ludwig Coellen (1921), and, for a more recent overview of the art-historical conception of "style", Wolfgang Bauer (1988). In art-historical or aesthetic contexts, the notion of "style" may be dated back to 1860 to Semper's two-volume study (Semper, 1860-1863). Indeed, a related conception of style was arguably already in use in Johann Joachim Winckelman (1755).

5. Fuller follows Joan Hart's (1993) article discussing the meaning of "style" as it emerges in the context of the correspondence between Panofsky and Mannheim (Fuller, 2000, p. 55n.). Fuller disputes the relevance of Fleck's thought for Kuhn (Fuller, p. 60n.), ergo for Fuller, the connection of style is less important than tracing the fortunes of Ernst Gombrich's (tellingly and literally, on Fuller's parsing of it) progressive ideal of perspective (Fuller, pp. 52ff.). For a more contextually situated discussion both of that correspondence and the scientific context in which Fleck's term makes its appearance, see Harwood (1993).

6. Some, most notably Fuller on Gombrich in the heady context of the Warburg Institute, have read the relation between art and science (for Fuller, "Art = Science") as that between iconography and structure (Fuller, 2000, pp. 51-70). In addition, if we note Nietzsche's reliance on an affine conception of "style" in his philosophy (variously qualifying art, politics and human character as such), it is patent that the concept of "style", then as now, enjoyed a wide and inspiring metaphoricity.

7. For this reason, Fleck's critical notion of thought collectives, as intrinsic to the progress of science as such, contradicts the dominant, historically ideological ideal of scientific genius and the achievement of Western liberal individualism. See Harré (2002) and Ziman (2002); see also Ziman (1995). But, beyond this, see further Golinski (1998).

8. For biographical details, see Schnelle (1982). See too Schnelle (1986, pp. 3-36), Schäfer and Schnelle (1983, pp. 9-34), and Dorobiski (1987, pp. 6-11).

9. Stefan Winneke (1992), makes this claim but other authors who could be drawn upon to echo this contention include Lothar Schäfer, Schnelle, and, indeed, Robert K. Merton, who was decisive in finally bringing about an English translation of Fleck's 1935 book. Winneke lists a broad range of scholars who have, rather more independently of Kuhn's ultimately diffident acknowledgement of Fleck's influence than not, explored the dimensions of both that influence as well as other directions of the same. In this latter range, Winneke includes Wilhelm Baldamus as the scholar who first set Schnelle to work on Fleck in the first place. For Baldamus, the success of Kuhn's work was (ironically enough) directly proportional to its indebtedness to Fleck's work (Baldamus, 1979, pp. 213-233; see also Baldamus, 1972, pp. 276302). Winneke also cites Ohe (1971), Merton (1977), and Baldamus (1976, 1977, 1979), as well as Schnelle and Baldamus (1978). See also Tsouyopoulos (1982).

10. Kockelmans (1975) has explored the relation between the conception of science within the natural and social sciences, to show that, however counter-intuitively for some, the natural sciences constitute not only the theoretical paradigm for the social sciences but the historical precedent for the same. The social 
sciences are not more primitive or less developed versions of the natural sciences and are thus not developmentally prior to them. This also means that such sciences ought not be expected to evolve increasingly more mathematical or logicized variants of themselves in the future.

11. See Bruno Latour's more or less uncomprehending, certainly pained efforts to make his own pro-science orientation as clear as possible (Latour, 1999).

12. Shapin and Schaffer (1985), Butterfield (1957 [1949]), Crombie (1952), Duhem (1913-1959). For a comparative discussion of Duhem and the peripheral limitations attending the reception of Duhem's historical focus, see Babich (1989, pp. 175-221). See also Dear (1995). For a general overview of the history of the scientific revolution and its contexts, see Cohen (1994), and for a specialized, more ethnographically influenced account of the history of science, crossing socio-historical borders, see Golinski (1998). For a reading of the history of alchemy and the origins of scientific chemistry, see Principe (1998). For the internal history of philosophy of science, see Giere and Richardson (1996), Friedman $(1999,2000)$. As a caution, it should be noted that such an attention to history and interpretive context in the same mainstream tradition as Toulmin, Harré, and Ziman is also what permits Jardine (2000 [1991]) to endorse a hermeneutic turn as he does us in the recent (re)edition of his 1991 book, a book perpetuating the similarly mainstream philosophical habitus of leaving continental philosophers like Patrick A. Heelan (and so many others) unnamed and hence out of account (see Babich, 2002a), while co-opting the larger iconic names (like Gadamer's own): an iceberg-chipping strategy which leaves the realm of needed reflection and reception as unfathomed as ever before, yielding conclusions of inevitably ultimately, limited or feeble weight. Until a modest focus becomes a word not for politic exclusion and selective inclusion but integrity and pluralistic respect and sensibility, it will end up, as Jardine's book ends up, in its earlier as in its later instaurations, drawing a conservative line in the dust, that like Toulmin's fine recommendation at the end of his book, Cosmopolis (Toulmin, 1992), needs far more than conviction but vital and critical action to back it up.

13. See Toulmin (2002, pp. 25-29). Also see Zimon (2002, pp. 203-217), and Harré (2002, pp. 219-229). See also Ziman (1995). Beyond this, see Golinski (1998) or any of Latour's works including, if one accounts for a certain self-revisionism, Latour (1999).

14. Steve Fuller brought this rather relevant detail to the author's attention. And I here underline that I take this report, a perfect piece of gossip, on perfect faith. Hearsay is hearsay.

15. See for a specific discussion of this credulity - and its limits-MacIntyre (1999, pp. xv-xvii).

16. Sorrel (1991).

17. How could it happen that scientists not be asked to vet an article on science-as if the evening news did not constantly present scientists happily saying speculative things about genetic engineering or evolution or even (please let's do think of Carl Sagan) astronomy and evolution, in one blow, unmasked or debunked by other scientists just as happily as misleading, overstated, and even erroneous. See for an overview and fuller discussion, Babich (2002a); an earlier version appeared as Babich (1997).

18. Hacking (1999), Latour (1999).

19. This may be one of the reasons for Fuller's impatiently cavalier dismissal of the role of Fleck not only in Kuhn but also for the very sort of social studies of science Fuller himself advocates.

20. See in particular, Dear (1995, Chap. 1).

21. This is the substance of the concluding reflections of Fleck (1986 [1947]).

22. Certain sociologists have observed that Fleck's idea of collective knowledge is abrogated by the very idea, as it were, of "intellectual property" and the very observable struggle in science for the ownership of an idea and the authority and power deriving from such influential ownership. Fleck himself describes this struggle concerning the possession of "Salvarsan" or the emergence of a single fact (like the Wasserman test) in his book. But the notion of a thought collective and its associated style for Fleck concerned the dynamic of research and discovery, the genesis, that is to say and the development of the then and thus emergent "fact". Tribal thinking or mindless identification with a research collective does not follow from Fleck's description.

23. Note that Kuhn's self-deprecation indicates a language competence that itself requires a hermeneutic articulation, different as it is from the case far more routine among American philosophers today of not being able to read German at all. In the same way, we note Kuhn also reports that he likewise read and spoke French very haltingly, a facility which was likewise different from illiteracy, as his own autobiographical reflections make clear in his recollection of his time during and after World War II in France where what he, as a military expert, was able to do then required just as much ability in French as he similarly disavows with a scientist's characteristic diffidence-a point of self-deprecating irony further attested by the praise of the quality of his French which he received from Parisians.

24. This insight is hardly a resultant of recent events, but it is now unmistakable in the wake of the dramatic 
demonstration of the limits of that same image of "democracy" afforded by the very events of the 2000 US presidential election and judicial decision regarding the undecided results of the same.

25. Kuhn did not credit Fleck beyond his famous prefatory characterization of Fleck's book as "an essay that anticipates many of my own ideas" and situating those same "ideas" in what Kuhn (1970, p. vii) called "the sociology of the scientific community". Baldamus (1979, p. 232) explains the sociological process of the dissemination of ideas from Fleck to Kuhn as follows: "Als schließlich die Bedeutung Flecks von Kuhn entdeckt wurde, führte dessen eigenmächtige Verarbeitung des Fleckschen Gedankenguts zu einem verblüffenden Rezeptionserfolg. Indem Kuhn aus dem Werk Flecks nur solche Bestandteile übernahm, die sich sinngemäß den Bedürfnissen der sechziger Jahre anpassen ließen, wurde jene Kritik [gemeint ist Flecks radikale Kritik an der zeitgenössischen Wissenschaftsphilosophie] entschärft und dadurch im Prinzip erst diskutabel, d. h. rezeptionsfähig."

26. Together with the conceptual tension evident in the periphrastic origins of the word paradigm, its metaphorical and metonymic trajectory contributes to the multiplicity of meaning that is so often attributed to Kuhn's term (beginning with Masterman, 1970).

27. See too the more comprehensive introduction by Schäfer and Schnelle in Fleck (1980, pp. vii-xlvii).

28. Note however that Fuller also seems to waver on his own conviction of the lesser relevance of Fleck's importance for Kuhn when he refers to Gustave Le Bon's invention of mass psychology (Fuller, 2000, p. $295 \mathrm{n}$ ), and perhaps he wavers as he does as he shares the claim of what he names the original "professional sociologists" who reviewed Fleck's book as "disturbed by his use of the term 'collective', with its strong industrial socialist overtones" (Fuller, 2000, p. 211n).

29. Fuller (2000).

30. As Fleck's notion of thought style implies, and just as Nietzsche argues, Kuhn could find in Fleck only what he had eyes to see, or ears to listen for. Hence, what exceeded Kuhn's capacity for understanding he simply overlooked. Kuhn's mistake lay—and with regard to Fleck he had only one —in assuming that the history and sociology of ideas was a properly established or developed discipline with a patent and received structure. A scientist by training and not a historian, Kuhn could not have guessed that nothing could be further from the truth in the social dynamic one author has famously dramatized as the "two cultures" and the still enduring abyss between the same.

31. This would mean, to oppose the dominant reading, expressed by Schäfer (1977) in his reflections on Fleck's reception by comparison with Kuhn's own influence, that at the very least, such a reliance shows less Kuhn's prescience than his opportunism.

32. Schäfer thus explicates the very problem of contemporary analytic philosophy of science as the dominant thought style possible in and for philosophy of science (Wissenschaftstheorie). For Schäfer, Kuhn is little more than Fleck's more marketable (or, as Baldamus expressed it: rezeptionsfähig) epigone. See Schäfer (1977).

33. The "very idea" of the history of science was conceptually problematic — and in many ways, it continues to be so, if we are to believe Jardine's mild and all-too-conservative warning (Jardine, 2000 [1991]), and we should. A recent review of the disciplinary relationship between the philosophy of science and the history of science shows that this tension remains-although it is manifestly clear that the philosophy of science can no longer insist, as a reconstructivist perspective could argue (to wit, Lakatos's famous quip), that it is too bad for science if it does not in historical fact accord with theoretical accounts of the logic of scientific discovery or invention. And if talk of thought collectives and thought styles was problematic, to combine the former with the idea of the history (specifically, fatally, expressed as the genesis and development) of a fact was exactly shocking to the logical mindset of the philosophy of science.

34. For a discussion of Nietzsche, see Babich (1994). For Nietzsche's connection with Kant in the context of science, see Babich (1999, pp. 1-13). The critical dynamic of questioning both what we name as true and what we regard as error is the keystone of Kant's entire philosophy of science. This emphasis on questioning is Kant's meaning when he writes, "The aesthetic design of the scientific question effects its judgment power" (Kritik der reinen Vernunft, Bxiii). Rather than a science based solely on observation (and inductive regress), which would be no science at all in the image of logic and mathematics, Kant resolves the Humean problem of induction in the Preface to the second edition of the Critique of Pure Reason in the empirical practice of questioning because the question (or experiment) both concedes and exploits the epistemological limitations of reason (Bix) and experience (cf. A124-126). Just as mathematics owes its scientific integrity to the axiomatic character of its conceptual groundwork, so physics operates with axioms or defining assumptions on both theoretical and objective levels, that is both in its fundamental concepts and in its experimental processes (B241/A196; A713/B741-A727/755). Two different readings of Kant's philosophy of science are useful here if they both remain — for different reasons - oblique to the traditional or "received" account of the philosophy of science as such: the first providing an architectonic or schematic of the Kantian schema (Buchdahl, 1992) and the second insightfully bridging Kant's first 
and third critiques in Heidegger's interpretation of Kant (Kerszberg, 1997). An excellent historical (and still exactly analytic) account is Friedman (1992).

35. This is the practical point of "going back to the drawing board" in a research context.

36. This opposes the casual presumption of one generalist in the history of philosophy, who thoughtlessly invokes the presentist viewpoint (he is not better on Nietzsche) that "what was once believed true is now known to be false, like the cases of astrology or alchemy" (Pippin, 2000, p. 136). Similar references may be sought in the literature of philosophy, particularly with reference to science or truth, almost at random.

37. And Fleck was all for abolishing that unitary and reified perspective as obstacle to a dynamic conception of a disease.

38. This comment contra the ideal of homeostasis is the point of Canguilhem's often cited remark on health as an emergent property: "Health is a margin of tolerance for the inconsistencies of the environment. To be in a good health means being able to fall sick and recover-it is a biological luxury" (Canguilhem, 1991, p. 199).

39. Aristotle's original assertion is that "the organ of sight is not only affected by, but also acts upon, its object. For in extremely clean mirrors, when women look into them during their menstrual period, the mirror surface takes on a sort of blood-red cloud. In fact, if the mirror is a new one, it is not easy to get the stain out, although it is easier with an old one" (Aristotle, 1990, pp. 89-91).

40. Saunders (2002, pp. 304-305ff.).

41. It is significant in this context that the larger number of sociological discussions, presumably more under the influence of Foucault and on Fleck, understand the term "social construction" of diseases to refer to a kind of parallel definition of the disease in the mind of the socius rather than having anything to do with the factual genesis and development of the scientific or medical concept. Fleck's is an aetiological and hence more epistemological concept.

42. See Lewontin (1993) for a provocative reflection on the relationship between ambient or non-microbial factors and virulent disease or epidemiology.

43. It is relevant that the co-workers to be found for this discipline lacked the requisite background for Fleck's conception and that Fleck himself, although assured of funding support (in an unusual reversal of circumstances for a research scientist), would not cooperate in the formation of such a tradition (the method of medical research science, as he understood it, precluded any systemic or dynamically complex science as leukergy). Thus modern medicine took only the most straightforward index of a much more complex phenomenon because it lacked the conceptual framework for the diagnostic information that Fleck could derive from leukergic immune response. See Cohen and Schnelle (1986); see also the editors' preface to Fleck (1980, pp. xv-xvii).

44. Thus Fleck (1979, p. 21) writes, "Syphilis is not to be formulated as "the disease caused by Spirochaeta pallida'." For Fleck, such statements are problematic because "syphilis as such does not exist" (p. 39), a claim that he makes not to deny the disease but to point to the inadequacy of the classic germ carrier theory of disease. For Fleck, anticipating today's increased attention to the role of the immune system and the organism as a whole, the disease entity (so-called) is but one aspect, because disease requires more the presence of infectious agents: perfectly healthy individuals carry such "disease agents" without being themselves ill. Illness or sickness is a complex state rather than a state betraying the presence of an alien invading element interior to an otherwise hermetically secure or integral biological system.

45. This same insight has been extended, in a direct line from Fleck's work, to oncology. See Zajicek (1992, pp. 304-305).

46. Nietzsche (1980, Vol. 9, p. 503) writes: "Wir müssen das Irren lieben und pflegen, es ist der Mutterschooß des Erkennens."

\section{References}

Aristotle (1990) Parva naturalia II 459b23-460a23, in: D. Gallup (Ed.) Aristotle on Sleep and Dreams: A Text and Translation with Introduction, Notes and Glossary (Peterborough, Ontario, Broadview Press), pp. 89-91.

Babich, B. (1989) Continental philosophies of science: Mach Duhem Bachelard, in: R. KEARNEY (Ed.) Continental Philosophy in the Twentieth Century (London, Routledge), pp. 175-221.

Babich, B. (1994) Nietzsche's Philosophy of Science: Reflecting Science on the Ground of Art and Life (Albany, State University of New York Press).

Babich, B. (1997) The hermeneutics of a hoax, Common Knowledge, 6(2), pp. 23-33. 
BABICH, B. (1999) Nietzsche's critical theory: the culture of science as art, in: BABICH (Ed.) Nietzsche, Epistemology and Philosophy of Science: Nietzsche and the Sciences II (Dordrecht, Kluwer), pp. 1-13.

BABICH, B. (2002a) Sokal's hermeneutic hoax: physics and the new inquisition, in: BABICH (2002b, pp. 67-78).

Babich, B. (Ed.) (2002b) Hermeneutic Philosophy of Science, Van Gogh's Eyes, and God: Essays in Honor of Patrick A. Heelan, S.f., Boston Studies in the Philosophy of Science, Vol. 225 (Dordrecht, Kluwer).

Baldamus, W. (1972) The role of discoveries in social science, in: T. SHanin (Ed.) The Rules of the Game (London, Heinemann), pp. 276-302.

Baldamus, W. (1976) The Structure of Sociological Inference (London, Heinemann).

Baldamus, W. (1977) Ludwik Fleck and the development of the sociology of science, in: P.R. GLEICHMANN et al. (Eds) Human Figurations: Essays for Norbert Elias (Amsterdam, Rodopi).

Baldamus, W. (1979) Das exoterische Paradox der Wissenschaftsforschung. Ein Beitrag zur Wissenschaftstheorie Ludwik Flecks, Zeitschrift für allgemeine Wissenschaftstheorie, 10, pp. 213-233.

Baltas, A., Gavroglu, K. \& Kindi, V. (2000) A discussion with Thomas Kuhn, in: KuHN (2000, pp. 255-323).

BAuER, W. (1988) Form, Struktur, Stil: Die formanalytischen und formgeschichtlichen Methoden, in: H. BELTiNG et al. (Eds) Kunstgeschichte: eine Einführung (Berlin, Reimer), pp. 151-168.

Buchdahl, G. (1992) Kant and the Dynamic of Reason (London, Blackwell).

Butterfield, H. (1957 [1949]) The Origins of Modern Science 1300-1800 (London, Bell).

Canguilhem, G. (1991) The Normal and the Pathological, C.K. FawcetT (Trans.) (New York, Zone Books).

Coellen, L. (1921) Der Stil in der bildenden Kunst. Allgemeine Stiltheorie und geschichtliche Studien dazu (Traisa, Darmstadt, Arkadienverlag).

Cohen, H.F. (1994) The Scientific Revolution: A Historiographic Survey (Chicago, IL, University of Chicago Press).

Cohen, R.S. \& Schnelle, T. (Eds) (1986) Cognition and Fact: Materials on Ludwik Fleck, Boston Studies in the Philosophy of Science, Vol. 87 (Dordrecht, Reidel).

Crombie, A.C. (1952) Augustine to Galileo: The History of Science, AD 1100-1700 (London, Heinemann).

DeAR, P. (1995) Discipline and Experience: The Mathematical Way in the Scientific Revolution (Chicago, IL, University of Chicago Press).

Dorobiski, A. (1987) Zur Wissenschafts- und Erkenntnisauffassung von Ludwik Fleck, Dissertation, Humboldt-Universität Berlin.

Duhem, P. (1913-1959) Le Système du monde: Histoire des doctrines cosmologiques de Platon à Copernic (Paris, Hermann).

Fleck, L. (1979) The Genesis and Development of a Scientific Fact, F. Bradley \& T.J. Trenn (Trans.) (Chicago, IL, University of Chicago Press).

FLECK, L. (1980 [1935]) Die Entstehung und Entwicklung einer wissenschaftliche Tatsache (Frankfurt am Main, Suhrkamp).

FLECK, L. (1986 [1935]) Scientific observation and perception, in: CoHEN \& SCHNELle (1986, pp. 59-78).

FleCK, L. (1986 [1947]) To look, to see, to know, in: CoHEN \& SCHNELle (1986, pp. 129-151).

FleCK, L. (1986 [1960]) Crisis in science, in: CoHEN \& SCHNELle (1986, pp. 153-158).

Friedman, M. (1992) Kant and the Exact Sciences (Cambridge, MA, Harvard University Press).

Friedman, M. (1999) Reconsidering Logical Positivism (Cambridge, Cambridge University Press).

Friedman, M. (2000) Parting of the Ways: Carnap, Cassirer, Heidegger (Chicago, IL, Open Court).

Fuller, S. (2000) Thomas Kuhn: A Philosophical History for Our Times (Chicago, IL, University of Chicago Press).

GiERE, R.N. \& Richardson, A.W. (Eds) (1996) Origins of Logical Empiricism (Minneapolis, University of Minnesota Press).

Golinski, J. (1998) Making Natural Knowledge: Constructivism and the History of Science (Cambridge, Cambridge University Press).

HACKING, I. (1982) Language, truth and reason, in: M. Hollis \& S. Lukes (Eds) Rationality and Relativism (Oxford, Oxford University Press), pp. 48-66.

HACKING, I. (1983) Representing and Intervening (Cambridge, Cambridge University Press).

Hacking, I. (1992) 'Style' for historians and philosophers, Studies in History and Philosophy of Science, 23, pp. $1-23$.

HaCKIng, I. (1999) The Social Construction of What? (Cambridge, MA, Harvard University Press).

HARRÉ, R. (2002) Science as the work of a community, in: BABICH (2002b, pp. 219-229).

HART, J. (1993) Erwin Panofsky and Karl Mannheim: a dialogue on interpretation, Critical Inquiry, 19, pp. 534-566. 
Harwood, J. (1993) Styles of Scientific Thought: The German Genetic Community, 1900-1933 (Chicago, IL, University of Chicago Press).

JARDINE, N. (2000 [1991]) The Scenes of Inquiry (Oxford, Oxford University Press).

Kerszberg, P. (1997) Critique and Totality (Albany, State University of New York Press).

Kockelmans, J.J. (1975) Toward an interpretive or hermeneutic social science, Graduate Faculty Philosophy Fournal, 5, pp. 73-96.

KuHn, T.S. (1970 [1962]) The Structure of Scientific Revolutions (Chicago, IL, University of Chicago Press). KuHN, T.S. (1979) Foreword, in: FleCK (1979, pp. vi-xi).

Kunn, T.S. (2000) The Road Since Structure: Philosophical Essays, 1970-1993, with an Autobiographical Interview, J. Conant \& J. Haugeland (Eds) (Chicago, IL, University of Chicago Press).

Latour, B. (1999) Pandora's Hope: Essays on the Reality of Science Studies (Cambridge, MA, Harvard University Press).

Lewontin, R.C. (1993) Biology as Ideology: The Doctrine of DNA (New York, Harper).

MacInTyre, A. (1981) After Virtue (London, Duckworth).

MacIntyre, A. (1999) Preface, in: Babich (1999b, pp. xv-xvii).

Masterman, M. (1970) The nature of a paradigm, in: I. Lakatos \& A. Musgrave (Eds) Criticism and the Growth of Knowledge (Cambridge, Cambridge University Press), pp. 59-89.

Merton, R.K. (1977) The sociology of science: an episodic memoir, in: R.K. MERTON \& J. GASTON (Eds) The Sociology of Science in Europe (Carbondale, Southern Illinois University Press).

Nietzsche, F. (1980) Kritische Studienausgabe (Berlin, Walter de Gruyter).

OHE, W. VON DER (1971) Serendipity reconsidered: sociological and metatheoretical considerations regarding the occurence and appreciation of unanticipated research results, MA thesis, Marquette University.

PippiN, R. (2000) Gay science and corporeal knowledge, Nietzsche-Studien, 29, pp. 136-152.

PrinciPe, L. (1998) The Aspiring Adept: Robert Boyle and His Alchemical Quest (Princeton, NJ, Princeton University Press).

SAUNDERS, B. (2002) Grammar(s) of perception, in: BABICH (2002b, pp. 301-310).

SCHÄFER, L. (1977) Theorien-dynamische Nachlieferungen. Anmerkungen zu Kuhn-Sneed-Stegmüller, Zeitschrift für philosophische Forschung, 31, pp. 19-42.

SCHÄFER, L. \& SCHNELlE, T. (1980) Einleitung, in: FleCK (1980, pp. vii-xlvii).

SCHÄFER, L. \& SCHNElle, T. (1983) Die Aktualität Ludwik Flecks in Wissenschaftssoziologie und Erkenntnistheorie, in: L. SCHÄFER \& T. SCHNELlE (Eds) Ludwik Fleck: Erfahrung und Tatsache. Gesammelte Aufsätze (Frankfurt am Main, Suhrkamp), pp. 9-34.

SchNelle, T. (1982) Ludwik Fleck. Leben und Denken. Zur Entstehung und Entwicklung des soziologischen Denkstils in der Wissenschaftsphilosophie (Freiburg im Breisgau, Hochschulsammlung Philosophie).

Schnelle, T. (1986) Microbiology and philosophy of science. Lwow and the German Holocaust. Stations of a life: Ludwik Fleck (1896-1961), in: CoHEN \& SCHNELle (1986, pp. 3-36).

Schnelle, T. \& Baldamus, W. (1978) Mystic modern science? Sociological reflections on the strange survival of the occult within the rational mechanistic world view, Zeitschrift für Soziologie, 7, pp. 251-266.

SEMPER, G. (1860-1863) Der Stil in den technischen und tektonischen Künsten, oder praktische Aesthetik, 2 vols (Frankfurt).

ShapIN, S. (1996) The Scientific Revolution (Chicago, IL, University of Chicago Press).

Shapin, S. \& Schaffer, S. (1985) Leviathan and the Air Pump: Hobbes, Boyle and the Experimental Life (Princeton, NJ, Princeton University Press).

Sorrel, T. (1991) Scientism: Philosophy and the Infatuation with Science (London, Routledge).

Toulmin, S. (1992) Cosmopolis: The Hidden Agenda of Modernity (Chicago, IL, University of Chicago Press).

Toulmin, S. (2002) The hermeneutics of the natural sciences, in: BABICH (2002b, pp. 25-29).

Trenn, T.J. (1979) Preface, in: FleCK (1979, pp. xii-xix).

Tsouyopoulos, N. (1982) Auf der Suche nach einer adäquaten Methode für die Geschichte und Theorie der Medizin. Auseinandersetzung mit Ludwik Flecks «Entstehung und Entwicklung einer wissenschaftlichen Tatsache", Medizinhistorisches fournal, 17, pp. 20-36.

Winckelman, J.J. (1755) Gedanken über die Nachahmung der griechischen Werke in der Malerey und Bildhauerkunst (Dresden).

WINNEKE, S. (1992) Ludwik Fleck-Zur Wirkung eines Wirkungslosen, Arbeitskreis für Wissenschaftsgeschichte: Dialogo (Stuttgart).

WölfFlin, H. (1915) Kunstgeschichtliche Grundbegriffe. Das Problem der Stilentwicklung in der neueren Kunst (München, Bruckmann).

ZAJICEK, G. (1992) Ludwik Fleck: founder of the philosophy of modern medicine, Cancer fournal, 5/6, pp. 304-305.

Ziman, J. (1995) Of One Mind: The Collectivization of Science (Woodbury, NY, American Institute of Physics). Ziman, J. (2002) No man is an island, in: BABICH (2002b, pp. 203-217). 


\section{B. E. BABICH}

\section{Note on contributor}

Babette E. Babich is Professor of Philosophy at Fordham University in New York City and Adjunct Research Professor of Philosophy at Georgetown University in Washington, DC. She is the author of Nietzsche's Philosophy of Science (1994), compiling and contributing editor of two collections on Nietzsche and the Sciences (1999), published in the series Boston Studies in the Philosophy of Science, and editor of Hermeneutic Philosophy of Science, Van Gogh's Eyes, and God (2002). Author of the entry, "Continental Philosophy of Science: Mach, Duhem, and Bachelard", in Vol. 10 of the Routledge Encyclopedia of Philosophy (1996, 2003) and "On the Analytic-Continental Divide in Philosophy" in Prado (Ed.), A House Divided (2003), she is writing a book on Heidegger's philosophy of modern science and technology. Correspondence: Department of Philosophy, Fordham University, 113 West 60th Street, New York, NY 10023, USA. E-mail: babich@fordham.edu 